\title{
A second species of Furcraea Vent. (Agavaceae), F. tuberosa (Mill.) W.T.Aiton, naturalised in South Africa
}

\author{
Gideon F. Smith ${ }^{1}$ and Estrela Figueiredo 2 \\ ${ }^{1}$ Office of the Chief Director: Biosystematics Research and Biodiversity Collections, South African National \\ Biodiversity Institute, Private Bag X101, Pretoria 0001 South Africa / Acocks Chair, Schweickerdt Herbarium, \\ Department of Botany, University of Pretoria, Pretoria, 0002 South Africa / Centre for Functional Ecology, \\ Departamento de Ciências da Vida, Universidade de Coimbra, 3001-455 Coimbra, Portugal \\ (email: g.smith@sanbi.org.za). \\ 2 Department of Botany, P.O.Box 77000, Nelson Mandela Metropolitan University, Port Elizabeth, 6031 \\ South Africa / Centre for Functional Ecology, Departamento de Ciências da Vida, Universidade de Coimbra, \\ 3001-455 Coimbra, Portugal (email: estrelafigueiredo@ hotmail.com).
}

Summary: Furcraea tuberosa (Mill.) W.T.Aiton (Agavaceae) is recorded as having become naturalised in the Mpumalanga Province of South Africa. A description and illustrations of the species in South Africa are provided, and it is compared with $F$. hexapetala (Jacq.) Urb., with which it can be confused taxonomically. A key based on vegetative characters to distinguish among $F$. tuberosa, F. foetida (L.) Haw. and F. selloa K.Koch, the latter two being commonly grown or naturalised in South Africa, is included.

Zusammenfassung: Furcraea tuberosa (Mill.) W.T.Aiton ist in der Provinz Mpumalanga, Südafrika, verwildert. Eine Beschreibung und Abbildungen der Art in Südafrika ergänzen einen Vergleich mit $F$. hexapetala (Jacq.) Urb., mit welcher sie taxonomisch verwechselt werden kann. Zusätzlich wird ein Schlüssel veröffentlicht, um zwischen $F$. tuberosa, F. foetida (L.) Haw. und F. selloa K.Koch (die letzten beiden in Südafrika häufig angepflanzt oder verwildert, zu unterscheiden.

\section{Introduction}

The potential and real negative invasive impact of Furcraea foetida (L.) Haw., a widely grown agricultural crop and ornamental, on natural vegetation in various parts of the world is well documented (see Crouch \& Smith, 2011, and references therein). Along with Furcraea selloa K.Koch, an ornamental species that has become naturalised in some, especially mild-climate, regions of the world, these are to date the only species of the genus Furcraea Vent. that have been recorded as having become established away from their natural habitats. Recent fieldwork in the eastern parts of South Africa alarmingly revealed a further species, Furcraea tuberosa (Mill.) W.T.Aiton, as having become established in South Africa (Figure 1). The country has the richest succulent flora in the world (Smith et al., 1997) and its various habitats provide perfect growing conditions for succulents imported from other parts of the world for cultivation, especially since the natural enemies of these species are usually absent from the country (Walters et al., 2011). Unsurprisingly, the recording of exotic species newly naturalised in South Africa is ongoing. We here provide a description of, and illustrate, $F$. tuberosa as it is found in South Africa, and compare it with $F$. hexapetala (Jacq.) Urb., with which it can be confused. A key based on vegetative characters to distinguish among $F$. tuberosa, $F$. foetida and $F$. selloa K.Koch, the latter two being commonly grown or naturalised in South Africa, is included.

Distinguishing Furcraea tuberosa from $F$. hexapetala, $F$. foetida and F. selloa

Furcraea tuberosa is native to the Antilles. It is thought that it originated from Hispaniola (Haiti and the Dominican Republic), and that it was introduced by Haitian slaves to the eastern parts of Cuba, where it is naturalised especially near roads and small towns (Álvarez de Zayas, 1996). The species has some economic value as fibres of this plant are used by the Haitian people to produce hammocks and cordage (Álvarez de Zayas, 1996). F. tuberosa is close to $F$. hexapetala (Jacq.) Urb., but differs from that species in the teeth on the leaf margins being reddish (Figure 2) and often double or divided, while those 

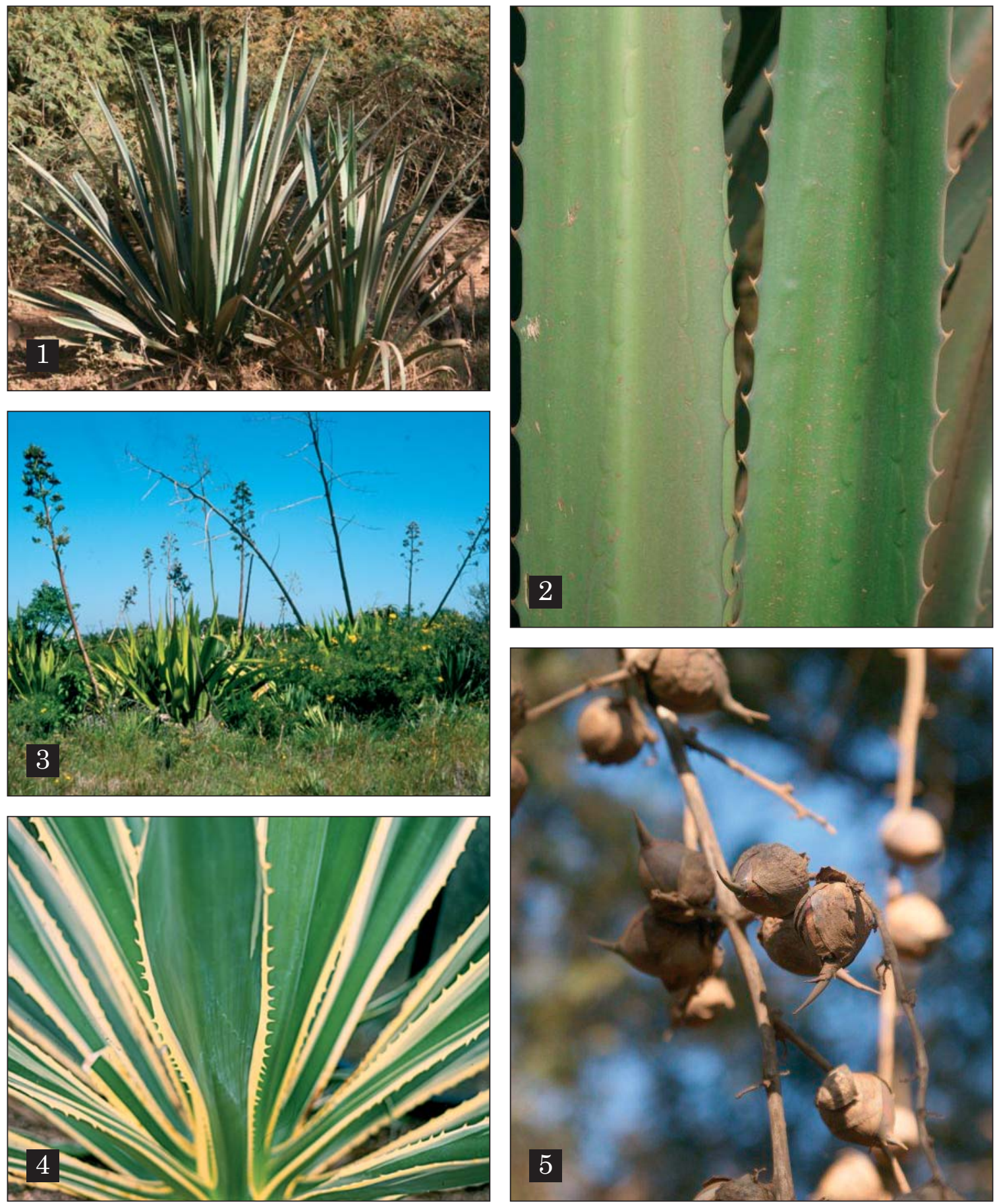

Figure 1. Clumps of $F$. tuberosa photographed near Lydenburg in South Africa's Mpumalanga Province. Figure 2. Close-up of the leaf margins and reddish brown teeth of F. tuberosa. Figure 3. F. foetida is widely naturalised in South Africa. Here near Port Elizabeth in the Eastern Cape Province it grows with a further invasive succulent, the smaller Agave angustifolia (shorter inflorescences and light bluish green leaves). Figure 4. The variegated form of F. selloa is widely cultivated in South Africa, especially in parts that have a mild climate. Figure 5. Globular bulbils carried on a branch of an inflorescence of F. tuberosa. Photos: Gideon F. Smith. 
of $F$. hexapetala are single and yellow to brown. $F$. hexapetala is also a larger plant (including the inflorescence) than $F$. tuberosa, with a trunk that can reach a length of $1.0 \mathrm{~m}$, while in $F$. tuberosa the trunk is much shorter, reaching a length of only $30 \mathrm{~cm}$. Further, the inflorescence of $F$. hexapetala is branched along its upper $3 / 4$, while in $F$. tuberosa it is branched in the upper $2 / 3$ (Álvarez de Zayas, 1996).

Two other species of Furcraea, F. foetida and $F$. selloa, are also widely encountered in South Africa. F. foetida (Figure 3) is naturalised in parts of South Africa (Crouch \& Smith, 2011), while $F$. selloa (Figure 4), although not recorded as having become naturalised, is a popular and widely grown garden subject.

\section{Invasive properties of Furcraea tuberosa}

No capsules, and therefore no seed production, were observed on the inflorescence branches of the specimens of $F$. tuberosa naturalised in northeastern South Africa. Specimens were also not found to sprout from the base. The primary reproductive mechanism of the species as found in its adopted country was clearly through the distribution of bulbils. These vegetative structures are produced in very large numbers on inflorescence branches and easily root where they fall (Figure 5). This gives rise to the establishment of expanding clusters of dense growth in close proximity to the mother plant.

\section{Nomenclature of Furcraea tuberosa}

The name Furcraea tuberosa was published by Aiton (1811) based on Agave tuberosa Mill. Although Aiton cited Willdenow (1799: 194) as reference, the name was published about 30 years earlier by Miller (1768) who is its correct author. Miller (1768) described the species as having “...a tuberous root and very long leaves, with spines on their edges..." and referred to it as "Aloe Americana radice tuberosa minor. Pluk Alm. 19." Plukenet (1696: 19) had listed it as including two types: "spinosa" (illustrated in Phytogr. Tab. 258 Fig. 1) and "non spinosa" (illustrated in Phytogr.

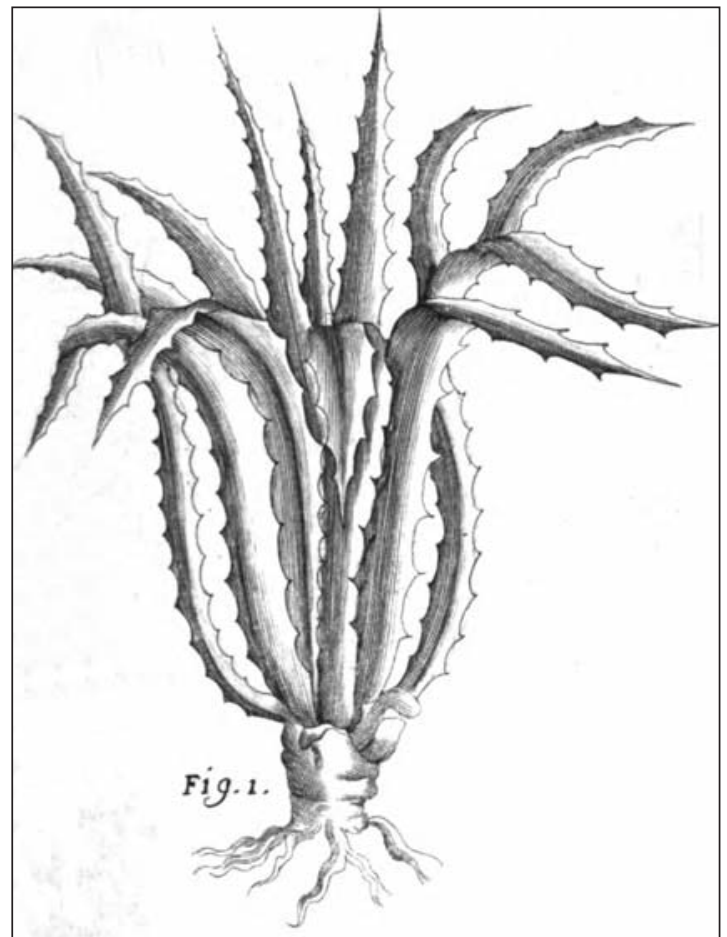

Figure 6. Type of Agave tuberosa Mill.: Plukenet (1692) Plate 258 Figure 1.

Tab. 258 Fig. 2). Miller (1768) was clearly referring to the spiny plants. The type of this name is therefore Figure 1 in Tab. 258 (Figure 6).

Furcraea tuberosa (Mill.) W.T.Aiton, Hortus Kew, $2^{\text {nd }}$ ed., 2: 303 (1811).

Basionym: Agave tuberosa Mill., Gard. Dict. $8^{\text {th }}$ ed., Agave no. 4 (1768). Type: Plukenet (1692) Plate 258 Figure 1.

Furcraea geminispina Jacobi, Vers. Syst. Ord. Agav.: 182 (1865).

For a more complete synonymy of $F$. tuberosa see Thiede (2001).

Large, perennial, rosulate leaf succulents. Stems absent or very short, less than $30 \mathrm{~cm}$ long.

Key based on vegetative characters to distinguish between Furcraea tuberosa, F. foetida and $F$. selloa

1. Leaves pronouncedly sword-shaped, leaf margins unarmed or armed with concolorous or brown teeth. 2

1'. Leaves narrowly attenuate, leaf margins armed with reddish brown teeth ................ $\boldsymbol{F}$. tuberosa

2. Leaf surfaces smooth; leaf margins unarmed or only basally armed with very few, widely spaced teeth

F. foetida

2'. Leaf surfaces sand-papery; leaf margins throughout armed with large, regularly spaced, concolorous or brown teeth F. selloa 
Rosettes open with semi-erect to spreading leaves. Leaves numerous, bright green, oblong-lanceolate and narrowly tapering, flat to canaliculate; leaf surfaces smooth, 1.0-1.8 m long; apex acute; slightly canaliculate; marginal teeth more or less $5 \mathrm{~mm}$ long, reddish brown. Inflorescence a multibranched, open panicle, 5-8 m tall, bulbilliferous, bulbils numerous, ovoid. Flowers about $4 \mathrm{~cm}$ long, in clusters of up to three; pedicels 6-10 $\mathrm{mm}$ long; tepals oblong, greenish white. Fruit not seen.

Voucher: South Africa, Mpumalanga Province. 2530 (Lydenburg): $2 \mathrm{~km}$ from the Weltevrede turn-off on the Machadodorp-Lydenburg road, direction Buffelskloof Nature Reserve. (-AB), in rich loamy soils in savanna vegetation, $25^{\circ} 08^{\prime} 19^{\prime \prime} \mathrm{S}$ $30^{\circ} 27^{\prime} 00^{\prime \prime}$ E, 28 April 2012, Gideon F. Smith \& Estrela Figueiredo 23 (PRE).

\section{Acknowledgements}

We are grateful to Dr. Alberto M. Álvarez Zayas of the Instituto de Ecología y Sistemática de Ciudad de la Habana in Cuba for kindly confirming the identity of Furcraea tuberosa as recorded in South Africa. Ms Ronell Klopper of the Biosystematics Division of the South African National Biodiversity Institute is thanked for information on the locality where Furcraea tuberosa was collected. An anonymous referee is thanked for comments on the manuscript.

\section{References}

Aiton, W. T. (1811). Hortus kewensis; or, a catalogue of the plants cultivated in the Royal botanic garden at Kew. $2^{\text {nd }}$ edn. Vol. II. Longman, Hurst, Rees, Orme, and Brown, London. Álvarez DE ZAYAs, A. M. (1996). El género Furcraea (Agavaceae) en Cuba. Ann. Inst. Biol. Univ. Nac. Autón. México, Ser. Bot. 67: 329-346.

Crouch, N.R. \& Smith, G.F. (2011). Agavaceae. Furcraea foetida: an invading alien in South Africa. Bothalia 41: 196-199.

Miller, P. (1768). Gardeners' Dictionary. $8^{\text {th }}$ edn. Printed for the Author, London.

Plukenet, L. (1692). Phytographia, pars tertia. Sumptibus Autoris, London.

Plukenet, L. (1696). Almagestum Botanicum. Sumptibus Autoris, London.

Smith, G.F., Van JaArsveld, E.J., ARnold, T.H., Steffens, F.E., Dixon, R.D. \& Retief, J.A. (eds.) (1997). List of southern African succulent plants. Umdaus Press, Pretoria.

Thiede, J. 2001. Agavaceae. Furcraea. In EGGLI, U. (ed.), Illustrated handbook of succulent plants: Monocotyledons. Springer Verlag, Berlin, pp. 78-84.

Walters, M., Figueiredo, E., Crouch, N.R., WinTER, P.J.D., Smith, G.F., Zimmermann, H.G. \& Mashope, B.K. (2011). Naturalized and invasive succulents of southern Africa. ABC Taxa, Vol. 11. The Belgian Development Cooperation, Brussels.

Willdenow, C.L. (1799). Species Plantarum. $4^{\text {th }}$ edn. Vol. 2. Impensis G.C.Nauk, Berlin. 